\title{
MAREK HENDEL
}

Uniwersytet Ekonomiczny we Wrocławiu, Polska • Wroclaw University of Economics, Poland

Michaє ŻEMŁA

Uniwersytet Pedagogiczny w Krakowie, Polska • Pedagogical University of Cracow, Poland

\section{Zrównoważona konsumpcja jako atrybut i uwarunkowanie rozwoju branży turystycznej w XXI wieku}

\section{Sustainable Consumption as Attribute and Condition of Tourism Sector Development in the 21st Century}

\begin{abstract}
Streszczenie: Celem artykułu jest ukazanie zrównoważonej konsumpcji jako współczesnego atrybutu i uwarunkowania rozwoju branży turystycznej. Przedstawiona w pracy koncepcja konsumpcji zrównoważonej oraz bezpośrednie odwołanie się do niej w turystyce pozwoliło autorom określić współczesne zmiany zachodzące na rynku usług turystycznych i podkreślić znaczenie troski o ochronę środowiska przyrodniczego we współczesnych wyborach konsumenta. Zdaniem autorów, ukierunkowanie konsumenta usług turystycznych na ochronę środowiska przyrodniczego wpisuje się w globalne zmiany zachowań konsumenckich, zauważalne również $\mathrm{w}$ innych sektorach usług. Jak podkreślają autorzy, w przypadku turystyki zmiana ta jest szczególnie ważna, bowiem powszechne uznawanie turystyki za formę działalności gospodarczej przyjaznej środowisku doprowadziło przez lata do nieodpowiedzialnego gospodarowania zasobami przyrody na rzecz jej rozwoju, a w konsekwencji do wielu nieodwracalnych zmian. Realizacja zasad zrównoważonego rozwoju w turystyce poprzez konsumpcję stanowi, w ocenie autorów, nie tylko element warunkujący rozwój turystyki, ale również istotną cechę wyróżniającą na tle innych sektorów usług. Odwołując się do pojęcia zrównoważonej konsumpcji, autorzy podkreślają również istotną rolę branży turystycznej w implementacji zrównoważonego rozwoju w turystyce.
\end{abstract}

\begin{abstract}
The aim of this article is to demonstrate the sustainable consumption as contemporary attribute and condition of the tourism sector development. The article presents the concept of sustainable consumption with direct reference to tourism that allowed the authors to define contemporary changes on tourism services market, highlighting the importance of protection of the natural environment in contemporary choices of consumers. In the authors' opinion, the focusing of consumers tourism services on this protection is in line with the global changes of consumers' behaviour that are visible in other services sectors. The authors also emphasize that this changes are particularly important for tourism. This relates to the universal recognition of tourism as a form of an environmentally friendly economic activity that over the years caused the irresponsible management of natural resources for development and consequently led to numerous irreversible changes. According to the authors, the implementation of the principles of sustainable tourism development by consumption is not only the element which decides on the development, it could be an important distinguishing feature in comparison to other services sectors. By referring to the concept of sustainable consumption the authors also emphasize the important role of tourism industry in implementation of sustainable development in tourism.
\end{abstract}

Słowa kluczowe: rozwój turystyki; turystyka zrównoważona; zrównoważona konsumpcja; zrównoważona konsumpcja w turystyce; zrównoważony rozwój 
Keywords: sustainable consumption; sustainable consumption in tourism; sustainable development; sustainable tourism; tourism development

Otrzymano: 19 grudnia 2015

Received: 19 December 2015

Zaakceptowano: 14 lipca 2016

Accepted: 16 July 2016

\section{Sugerowana cytacja / Suggested citation:}

Hendel, M., Żemła, M. (2016). Zrównoważona konsumpcja jako atrybut i uwarunkowanie rozwoju branży turystycznej w XXI wieku. Prace Komisji Geografii Przemysłu Polskiego Towarzystwa Geograficznego, 30(4), 187-197.

\section{WSTĘP}

Stale rosnąca pozycja sektora usług w gospodarkach współczesnego świata stała się cechą szczególną zmian gospodarczych zachodzących w XXI wieku. Ukierunkowanie na usługi zapoczątkowało proces zmian strukturalnych, których skutkiem było zmniejszenie w gospodarce udziału przemysłu wytwórczego. W konsekwencji to usługi bezpośrednio decydują o ekonomicznym, społecznym i kulturowym rozwoju współczesnych gospodarek, decydując jednocześnie o ich konkurencyjności i przyczyniając się do wzrostu produktywności w pozostałych sektorach (Czubała, Jonas, Smoleń, Wiktor, 2012).

Kształt struktury sektora usług w poszczególnych gospodarkach jest rezultatem zmian charakteru usług wynikających z rozwoju społeczno-gospodarczego. Flejterski, Klóska, Majchrzak (2005), na podstawie powyższego założenia, wyróżniają cztery fazy rozwoju sektora usług, w których szczególne miejsce zajmują usługi o charakterze konsumpcyjnym, w tym usługi turystyczne. Nieprzypadkowe jest wyróżnienie usług turystycznych - wiąże się przede wszystkim z dynamiką rozwoju turystyki, która od drugiej połowy XX wieku stała się jedną z największych i najprężniej rozwijających się gałęzi gospodarki.

Zachodzące zmiany na rynku usług związane są nierozerwalnie z pozycją konsumenta, który uznawany jest za podstawową siłę kształtującą wielkość i strukturę sektora usług (Rosa, 2005). Ciągłe modyfikacje decyzji konsumenta związane z wyborem środków i sposobów konsumpcji sprawiają, że rola konsumenta na rynku stale rośnie (Witek, 2011). Przykładem jest współczesny rynek usług turystycznych, gdzie wzrost wymagań i świadomości konsumenta uważany jest za jedną z jego najistotniejszych cech (Jedlińska, 2007).

Dynamiczny rozwój sektora usług i jego wpływ na współczesną gospodarkę wymaga analizy zmian zachodzących na rynku, w tym analizy umożliwiającej identyfikację czynników wpływających na rozwój poszczególnych usług. Na tej podstawie autorzy artykułu, ograniczając obszar badawczy do rynku usług turystycznych, starają się wskazać współczesne uwarunkowania rozwoju branży turystycznej, podkreślając szczególną rolę konsumenta. 


\section{CHARAKTERYSTYKA BRANŻY TURYSTYCZNEJ W XXI WIEKU}

Silna pozycja turystyki w strukturze gospodarek świata związana jest z jej dynamicznym rozwojem, dającym w rezultacie określone efekty gospodarcze. W 2012 roku turystyka zajmowała pierwsze miejsce na świecie w międzynarodowym handlu usługami, stanowiąc 40\% światowego handlu usług, 6\% całkowitego obrotu handlowego świata, dając 8,5\% globalnego zatrudnienia (Kurleto, 2013). Wyróżniony 2012 rok jest istotny ze względu na przekroczoną po raz pierwszy liczbę miliarda (1,035 mld) międzynarodowych wyjazdów turystycznych (UNWT0, 2013). Kolejne lata ukazują ciągły wzrost ruchu turystycznego na świecie i prognozują nieustanny wzrost zainteresowania podróżami turystycznymi - w 2013 roku to 1,087 mld wyjazdów, a w 2014 roku 1,138 mld (UNWTO, 2015).

Trwający proces rozwoju ruchu turystycznego na świecie sprawił, że ogólny sukces branży turystycznej zależy przede wszystkim od rozpoznania, a dalej od radzenia sobie ze zmianami czynników, m.in. ekonomicznych, politycznych, środowiskowych (Kurleto, 2013), oraz monitorowania rynku turystycznego, śledzenia uwarunkowań i szeroko pojmowanego otoczenia (Alejziak, 1999). Zmieniające się uwarunkowania gospodarcze, społeczne, środowiskowe i technologiczne decydują bowiem w szczególności o zmieniających się potrzebach, motywacjach i preferencjach turystów (Alejziak, 1999).

Spośród licznych uwarunkowań szczególnie istotny dla rozwoju branży turystycznej wydaje się kierunek zmian dotyczący charakteru relacji środowiska naturalnego z gospodarką. Pojawienie się koncepcji turystyki zrównoważonej jako idei wywodzącej się z zasad zrównoważonego rozwoju (Durydiwka, Kowalczyk, Kulczyk, 2010), która uwzględnia je w sposób kompleksowy w odniesieniu do gospodarki turystycznej (Niezgoda, 2006), miało decydujący wpływ na kształt rynku turystycznego. Zmiany zauważalne są także w zachowaniach konsumentów. Turyści coraz częściej zaczynają rozumieć, że ich działania mogą wpływać na inne dziedziny życia społecznego i gospodarczego (Niezgoda, 2011). Ukierunkowanie konsumenta i zmiana jego zachowań zaczęły również decydować o charakterze oferowanych produktów turystycznych (Meyer, 2010), sygnalizując podmiotom świadczącym usługi turystyczne potrzebę kształtowania oferty zgodnej z wymaganiami ochrony środowiska (Niezgoda, 2011).

\section{KONCEPCJA ZRÓWNOWAŻONEGO ROZWOJU TURYSTYKI JAKO WYRAZ REALIZACJI IDEI ZRÓWNOWAŻONEGO ROZWOJU W TURYSTYCE}

Wieloletnie doświadczenia krajów funkcjonujących zarówno w realiach gospodarki wolnorynkowej, jak i centralnie sterowanej pokazały, że niekontrolowany wzrost gospodarczy jako jedyny wyznacznik kierunków rozwoju nie spełnia założonej roli i prowadzi do wystąpienia szeregu dysfunkcji, zwłaszcza w dziedzinie degradacji środowiska naturalnego (Żemła, 2010b). Niekontrolowanemu wzrostowi gospodarczemu towarzyszą problemy, których nie obejmuje prosty rachunek ekonomiczny w postaci skutków społecznych nierównomiernego podziału dochodów czy następstw ekologicznych ekspansji przemysłowej. 
Zasadniczą zmianę przyniósł nowy paradygmat rozwoju oparty na trzech głównych wyznacznikach: równowadze ekologicznej, równowadze społecznej i kulturowej oraz równowadze gospodarczej (Turystyka i środowisko, 1994). W wielu opracowaniach (Sumień, 1998; Sztumski, 2006) lista ta jest rozszerzana o kolejne elementy ładu, najczęściej o ład przestrzenny i ład instytucjonalno-polityczny.

Rozwój oparty na powyższych zasadach określa się mianem rozwoju zrównoważonego (ang. sustainable development) i definiuje jako ewolucyjny proces przemian strukturalnych, ukierunkowany na poprawę jakości życia wszystkich istot dzisiaj i w przyszłości (Żabińska, 2000). W polskim prawodawstwie rozwój zrównoważony jest definiowany jako „taki rozwój społeczno-gospodarczy, w którym następuje proces integrowania działań politycznych, gospodarczych i społecznych, z zachowaniem równowagi przyrodniczej oraz trwałości podstawowych procesów przyrodniczych, w celu zagwarantowania możliwości zaspokajania podstawowych potrzeb poszczególnych społeczności lub ich obywateli, zarówno współczesnego, jak i przyszłych pokoleń" (Ustawa..., 2001: poz. 67, art. 3 pkt 50).

Takie ujęcie rozwoju zrównoważonego uwypukla współzależność ładów w rozwoju społeczno-gospodarczym oraz konieczność zachowania zasobów dla przyszłych generacji, zachowując przy tym zasadę sprawiedliwości między- i wewnątrzpokoleniowej. Rozwój taki oznacza również maksymalizowanie korzyści netto z rozwoju ekonomicznego, przy jednoczesnym zachowaniu użyteczności i jakości zasobów naturalnych w długim okresie (Niezgoda, 2006).

Zagadnienia zrównoważonego rozwoju pozostają w pełni aktualne w odniesieniu do obszarów recepcji turystycznej. Turystyka wywiera ciągły wpływ na środowisko, w którym funkcjonuje, zmieniając je w korzystnym kierunku - poprzez racjonalne kształtowanie, bądź niekorzystnym - przez niszczenie zasobów, a tym samym pomniejszając jego wartość (Chudy-Hyski, 2013). Turystyka bywa wprawdzie postrzegana jako jedna z najbardziej przyjaznych środowisku form działalności gospodarczej, jednak w przeciwieństwie do m.in. uciążliwego przemysłu ciężkiego z reguły korzysta z zasobów najbardziej wartościowych ekosystemów, stwarzając zagrożenie dla ostatnich, względnie naturalnych fragmentów przyrody.

Gwałtowny rozwój turystyki masowej w latach siedemdziesiątych XX wielu i towarzyszące mu silne dysfunkcje ekologiczne, społeczne i gospodarcze (Dziedzic, 1998; Kurek, 1999) rozwiały entuzjazm, jaki turystyka wcześniej budziła - jako alternatywa dla bardziej uciążliwych przyrodniczo form działalności gospodarczej.

Gospodarka turystyczna w każdej formie polega na wykorzystywaniu zasobów przyrody, co wymusza ciągłe śledzenie konsekwencji, jakie jej rozwój może spowodować w ekosystemie. Wytwarzanie produktu turystycznego zawsze odbywa się kosztem środowiska naturalnego, a ponieważ niemożliwa jest substytucja naturalnych walorów turystycznych, każde ilościowe lub jakościowe ich ograniczenie prowadzi do spadku atrakcyjności turystycznej danego regionu.

Istnieją zatem naturalne granice korzystania ze środowiska na potrzeby turystyki, poza którymi walory turystyczne ulegają takiemu ograniczeniu, że teren przestaje być atrakcyjny turystycznie (Jędrzejczyk, 1995). Granice te w literaturze są wyznaczane przez szereg wskaźników, budowanych na podstawie pojęć chłonności i pojemności turystycznej obszaru (Jędrzejczyk, 1995; Kruczek, Sacha, 1995). 
Idealne rozwiązanie, do którego powinno się dążyć, zostało w literaturze określone mianem turystyki zrównoważonej (ang. sustainable tourism) lub zrównoważonego rozwoju turystyki (ang. sustainable tourism development) (Żemła, 2010a). Turystyka zrównoważona to każda forma rozwoju turystycznego, zarządzania i aktywności turystycznej, która podtrzymuje ekologiczną, społeczną i ekonomiczną integralność terenów, a także zachowuje dla przyszłych pokoleń w niezmienionym stanie zasoby naturalne i kulturowe tych obszarów (Zaręba, 2010). Podobnie jak ma to miejsce w przypadku zrównoważonego rozwoju, opracowanie i wprowadzenie w życie turystyki zrównoważonej nie jest wolne od problemów. Brak precyzyjnego określenia tego, czym turystyka zrównoważona ma być, czym się charakteryzować (Eccles, 1995; Hunter, 1997), powoduje wielość i różnorodność poglądów lansowanych przez teoretyków oraz wdrażanych w życie rozwiązań praktycznych (Vera Rebollo, Ivars Baidal, 2003; Butler, 2005). Przyczyną takiego stanu rzeczy jest trudność operacjonalizacji koncepcji rozwoju zrównoważonego (Berry, Ladkin, 1997). Stąd obszar zagadnień, co do którego panuje zgodność opinii, dotyczy przede wszystkim bardzo ogólnie sprecyzowanych celów i zadań stawianych turystyce zrównoważonej, brakuje natomiast jednoznacznych wskazówek określających sposób realizacji tych celów i teoretycznej ich analizy.

\section{KONCEPCJA KONSUMPCJI ZRÓWNOWAŻONEJ W TURYSTYCE}

Zmiany w zachowaniach konsumentów, widoczne na wielu płaszczyznach (Borowska, 2013), oraz rosnący wpływ zasad zrównoważonego rozwoju na współczesne decyzje nabywcze konsumentów ukształtowały wiele koncepcji, które umożliwiły realizację celów zrównoważonego rozwoju w obszarze konsumpcji - przykładem jest konsumpcja zrównoważona. Łącząca szereg praktyk społecznych, gospodarczych i politycznych na poziomie jednostek, gospodarstw domowych, wspólnot, środowisk biznesowych i rządów (Kramer, 2011) konsumpcja zrównoważona spełnia zasady zrównoważonego rozwoju w sposób wielowymiarowy i wielopodmiotowy. Jednocześnie jej realizacja odbywa się w sposób ograniczony w stosunku do dóbr pochłaniających zbyt duże zasoby środowiska naturalnego, zgodnie z zasadą oszczędności gospodarowania dobrami (Włodarczyk-Śpiewak, 2011). Poziom konsumpcji zrównoważonej określić więc można jako „...konsumpcję dóbr materialnych i usług w stopniu wystarczającym, by zaspokajać podstawowe potrzeby i osiągać wyższą jakość życia, minimalizując zużycie zasobów naturalnych, materiałów szkodliwych dla środowiska, powstających na wszystkich etapach produkcji, nie ograniczając jednocześnie praw następnych pokoleń do takiej konsumpcji" (Kramer, 2011: 8).

W odniesieniu do turystyki, trudności związane z praktycznym wdrożeniem zasad zrównoważonego rozwoju wymagają w pierwszej kolejności wypracowania i określenia odpowiednich sposobów ich realizacji. Istotne w tym zakresie jest umiejętne kierowanie rozwojem turystyki oraz poszukiwanie takich form, które umożliwiłyby realizację zasad zrównoważonego rozwoju w możliwie jak najlepszy sposób (Żemła, 2013). Turystyka zrównoważona, uznawana za model idealny w ściśle zachowanych warunkach równowagi pomiędzy środowiskiem przyrodniczym, turystami, społecznością lokalną i usługodawcami turystycznymi (Durydiwka, Kowalczyk, Kulczyk, 2010), 
stanowi podstawę do rozważań na temat realizacji zasad zrównoważonego rozwoju w turystyce poprzez konsumpcję.

Jednym z ważnych problemów związanych z wdrożeniem zasad turystyki zrównoważonej jest dualny charakter negatywnego oddziaływania turystyki na środowisko. $\mathrm{Z}$ jednej strony są to straty związane $\mathrm{z}$ trwałym przekształceniem przestrzeni przez inwestycje turystyczne, z drugiej - straty związane z użytkowaniem tego środowiska przez turystów. 0 ile w pierwszym przypadku dostrzeżenie i w miarę możliwości minimalizacja strat jest możliwe, o tyle $\mathrm{w}$ drugim, m.in. ze względu na zmiany sezonowe $\mathrm{w}$ intensywności ruchu turystycznego oraz trudne do przewidzenia zachowania odwiedzających, jest to dużo trudniejsze. Tymczasem nawet w przypadku inwestycji tak uciążliwych dla środowiska, jak budowa ośrodków narciarskich, coraz częściej słychać głosy podkreślające, że najważniejszym problemem ekologicznym związanym $\mathrm{z}$ ich funkcjonowaniem jest masowy charakter ruchu turystycznego i jego konsekwencje w postaci spalin samochodów „zalegających” w powietrzu wąskich górskich dolin, zanieczyszczenia wód ściekami komunalnymi oraz zaśmiecenia (Kurek, 2004). Część z nich wynika jednak z samej skali ruchu turystycznego, w niewielkim stopniu zależąc od decyzji i zachowań konsumentów.

Zupełnie inaczej jest w przypadku pozostałych konsekwencji, gdzie wspomniany stopień znaczenia jest zdecydowanie inny. Zatem skala strat $w$ środowisku przyrodniczym pozostaje $\mathrm{w}$ pewnym stopniu zależna od zachowań wynikających z poziomu świadomości ekologicznej turystów i ich wyborów, takich jak np. wybór publicznej komunikacji zamiast własnego samochodu przy dojeździe do stoku narciarskiego, wybór obiektów noclegowych i gastronomicznych posiadających certyfikaty ekologiczne w zakresie wykorzystywania odnawialnych źródeł energii, segregacji odpadów i ich recyklingu itp. Zachowania te stanowią podstawę implementacji koncepcji zrównoważonej konsumpcji, a ich rozpowszechnienie, wraz z oczekiwanym wzrostem świadomości ekologicznej, spowoduje większe działania po stronie podaży, będące odpowiedzią na oczekiwania coraz liczniejszej grupy klientów. 0 ile w Polsce i wielu krajach europejskich zjawiska te są wciąż opisywane w czasie przyszłym, tak ich obserwacja możliwa jest od wielu lat w Stanach Zjednoczonych, gdzie najważniejsze ośrodki narciarskie ubiegają się o certyfikaty ekologiczne gwarantujące niski poziom zużycia wody i środków chemicznych do naśnieżania tras, wykorzystywania odnawialnych źródeł energii oraz uczestniczenia w akcjach ochrony i odbudowy przyrody w ekosystemach naruszonych przez inwestycje narciarskie (Hudson, 1996; Todd, Williams, 1996; Hudson, Miller, 2005; Smerecnik, Andersen, 2011).

Pojawienie się nowych czynników decydujących o rozwoju branży turystycznej, takich jak wzrost wymagań konsumentów i zmiana ich zachowań nabywczych, oraz wyłonienie się nowych modeli konsumpcji wymagają wdrożenia szczególnych działań przez branżę turystyczną. Jednym z nich jest ukierunkowanie branży turystycznej na konsumenta, a więc myślenie w kategoriach jego potrzeb i wymagań (Panasiuk, 2007). W efekcie wzrostu poziomu świadomości ekologicznej i zmian zachowań turystów pojawił się nowy konsument, który - chroniąc środowisko - skłonny jest zmienić swój dotychczasowy styl życia, przyzwyczajenia oraz model konsumpcji (Niezgoda, 2010). Konsument ten gotów jest za produkty ekologiczne (np. pobyt w ekohotelu) 
ponieść wyższe koszty zakupu, rezygnując z tańszych produktów masowych, gotów jest również zrezygnować z udogodnień estetycznych - przykładem są ekohotelowe łazienki, które mogą być skromniej urządzone niż w innych obiektach (Niezgoda, 2010).

Charakter przedstawionych zmian nie tylko sygnalizuje podmiotom świadczącym usługi turystyczne potrzebę kształtowania oferty zgodnej z ich wymaganiami. W momencie dostosowywania się do potrzeb nabywców branża turystyczna może zastosować rozwiązania proekologiczne, które pozwolą ograniczyć koszty stałe, minimalizując negatywne oddziaływanie na środowisko przyrodnicze. Branża turystyczna może w tym przypadku wystąpić w roli inicjatora edukacji ekologicznej społeczeństwa (Bohdanowicz, 2008), narzucając pewne ograniczenia w korzystaniu z zasobów, jednocześnie zachęcając do oszczędności w tym obszarze. Charakter zmian w tym przypadku będzie nie tylko jakościowy, ale i ilościowy.

Możliwe do zastosowania działania proekologiczne można przedstawić na przykładzie obiektów hotelarskich. Zredukowanie negatywnego wpływu na środowisko naturalne możliwe jest w kilku obszarach: gospodarce wodnej, energii elektrycznej, gospodarce odpadami, gospodarce produktami (Kłos, 2013). W obszarze gospodarki wodnej warto wspomnieć, iż turyści zużywają średnio kilka razy więcej wody niż lokalni mieszkańcy, wywołując często konflikty społeczne (Tourism Concern, 2012; Becken, 2014). Spośród licznych sposobów gospodarowania wodą, m.in. przez montaż w łazienkach urządzeń ograniczających zużycie wody, można to zużycie ograniczyć poprzez zachęcanie gości hotelowych do powtórnego wykorzystania ręczników kąpielowych (Kłos, 2013). Zastosowanie takich rozwiązań kształtuje proekologiczną postawę konsumenta, który zostaje postawiony przed dokonaniem świadomego wyboru. Niestety proekologiczne działania obiektów hotelarskich związane są głównie z czynnikiem ekonomicznym, na drugim planie stawiając troskę o środowisko przyrodnicze. Jednym z wyznaczników właściwej troski obiektów noclegowych o środowisko są certyfikaty ekologiczne, które pozwalają wyróżnić na rynku ośrodki kierujące się w działaniach głównie czynnikiem środowiskowym. Niestety nie wszystkie certyfikaty poddają właściwej ocenie obiekty, powodując rynkową asymetrię informacji (Pawlicz, Sidorkiewicz, 2013).

Element środowiskowy w przypadku turystyki zrównoważonej uznawany jest za dość szczególny. Zdaniem Buckleya (2012), z analizy przeprowadzonych badań naukowych w ostatnich czterech dekadach wynika, że ograniczenie negatywnego wpływu turystyki, poprzez m.in. umiejętne zarządzanie środowiskiem w praktyce, jest jednym z priorytetów badawczych na najbliższe lata. W odniesieniu do środowiska naturalnego ciągły wzrost konsumpcji dóbr i usług turystycznych stanowi dla turystyki zrównoważonej ogromne wyzwanie. Jej zadaniem bowiem jest niezmienne utrzymywanie wzrostu konsumpcji w formie jak najbardziej przyjaznej środowisku (Zaręba, 2010), uwzględniając przy tym warunki ekonomicznego i społecznego rozwoju (Niezgoda, 2006).

Zrównoważony kierunek zmian konsumpcji w turystyce wymaga szczególnej oceny znaczenia poszczególnych podmiotów w jej realizacji. Przypisanie ról poszczególnym podmiotom - w tym branży turystycznej - oraz identyfikacja instrumentów możliwych do zastosowania w nowej sytuacji rynkowej to tylko jedne z licznych przykładów działań możliwych do przeprowadzenia w tym obszarze. Możliwość realizacji koncepcji 
konsumpcji zrównoważonej wymaga na wstępie wprowadzenia przez podmioty branży turystycznej samoograniczenia, które polega na odstąpieniu od kierowania się przy prowadzeniu działalności tylko i wyłącznie celem osiągnięcia największych bieżących korzyści finansowych (Durydiwka, Kowalczyk, Kulczyk, 2010).

\section{ZAKOŃCZENIE}

Zrównoważona konsumpcja, uznawana za interpretację zrównoważonego rozwoju w sferze spożycia, prowadzi do refleksji nad problemami, które wykraczają poza interesy jednostki podczas dokonywania zakupu dóbr i usług oraz ich konsumowania (Zalejski, Faszczewska, 2012). Szeroki zakres oddziaływań konsumpcji zrównoważonej (Kiełczewski, 2012) nakazuje spojrzeć na możliwość realizacji tejże koncepcji na różnych rynkach usług, zwłaszcza na rynku dóbr i usług turystycznych. Zachodzące na nim przemiany spowodowane są licznymi uwarunkowaniami o różnym charakterze oraz zasięgu oddziaływania i w sposób szczególny wpływają na stronę podażową, decydując o funkcjonowaniu podmiotów w niej uczestniczących (Zdon-Korzeniowska, Rachwał, 2011). Ze względu na silne powiązania turystyki z wszelkimi tendencjami w zakresie potrzeb, motywacji i udogodnień konsumentów współcześnie to właśnie konsumpcja ma wyraźny wpływ na obecny kształt i funkcjonowanie rynku turystycznego, nadając również istotny kierunek zmian (Dąbrowska, 2006).

W. Alejziak uważa, iż „...zmiany i przewartościowania zachodzące w modelu życia i charakterze konsumpcji mają nie tylko decydujący wpływ na obecny kształt i funkcjonowanie rynku turystycznego, ale - według większości prognoz - będą nadawać ton i kierunek zmianom w przyszłości” (Alejziak, 1999: 192). Podobnego zdania jest również M. Żemła, który uważa, że „...proces podejmowania decyzji przez konsumentów na rynku usług turystycznych podlega ciągłym modyfikacjom wynikającym z przemian w otoczeniu, zwłaszcza kulturowym, i konieczne wydają się dalsze jego badania" (Żemła, 2010a: 89). Szczególna specyfikacja rynku turystycznego wymaga, by w sposób specjalny odnieść się w analizie koncepcji konsumpcji zrównoważonej również do turystyki.

Konsumpcja zrównoważona, uważana za trend w zachowaniach współczesnych konsumentów (Wasilik, 2014), jest niewątpliwie istotnym uwarunkowaniem wpływającym na funkcjonowanie sektorów usług. Kierunek zmian oparty na zrównoważonej konsumpcji pojawił się również w świadczeniu usług turystycznych. Branża turystyczna reaguje i dostosowuje się do zmieniającej się sytuacji rynkowej, co decyduje o jej kształcie i funkcjonowaniu, odmiennym od istniejącego do tej pory. Realizacja zasad zrównoważonego rozwoju w turystyce poprzez konsumpcję stanowi w tym przypadku nie tylko element warunkujący jej rozwój, stanowić może również istotną cechę wyróżniającą na tle innych sektorów usług. Niewątpliwie jej znaczenie stale rośnie, nadając ton zmianom i decydując o ich przebiegu. Dlatego tak ważne w dyskusji o praktycznym wdrożeniu zasad zrównoważonego rozwoju jest bezpośrednie odniesienie do poszczególnych sektorów usług, a dalej do podmiotów odpowiedzialnych za ich funkcjonowanie. 


\section{Literatura}

\section{References}

Alejziak, W. (1999). Turystyka w obliczu wyzwań XXI wieku. Kraków: Wydawnictwo Albis.

Becken, S. (2014). Water equity - Contrasting tourism water use with that of the local community. Water Resources and Industry, 7-8, 9-22.

Berry, S., Ladkin, A. (1997). Sustainable tourism: a regional perspective. Tourism Management, 18(7), 433-440.

Bohdanowicz, P. (2008). Turystyka a świadomość ekologiczna. Toruń: Wydawnictwo Adam Marszałek.

Borowska, A. (2013). Tendencje we współczesnej konsumpcji w dobie globalizacji i wobec wyzwań zrównoważonego rozwoju. Handel Wewnętrzny, 71, 66-73.

Buckley, R. (2012). Sustainable tourism: Research and reality. Annals of Tourism Research, 2(39), 528-546.

Butler, R.W. (2005). Developing the destination: Difficulties in achieving sustainability. W: W. Alejziak, R. Winiarski (red.). Tourism in Scientific Research. Kraków-Rzeszów: Wydawnictwo Akademii Wychowania Fizycznego w Krakowie i Wyższej Szkoły Informatyki i Zarządzania w Rzeszowie, 33-45.

Chudy-Hyski, D. (2013). Bezpośrednie i pośrednie oddziaływanie turystyki na środowisko przyrodnicze. W: D. Chudy-Hyski, M. Żemła (red.). Turystyka bardziej przyjazna. Wybrane zagadnienia minimalizacji negatywnego wpływu turystyki na środowisko przyrodnicze. Katowice: Wydawnictwo Górnośląskiej Wyższej Szkoły Handlowej w Katowicach, 25-38.

Czubała, A, Jonas, A., Smoleń, T., Wiktor, J.W. (2012). Marketing usług. Warszawa: Wydawnictwo Wolters Kluwer.

Dąbrowska, B.J. (2006). Rozwój usług turystycznych w warunkach globalizacji. Gdańsk: Wyższa Szkoła Turystyki i Hotelarstwa w Gdańsku.

Durydiwka, M., Kowalczyk, A., Kulczyk, S. (2010). Definicja i zakres pojęcia „turystyka zrównoważona”. W: A. Kowalczyk (red.). Turystyka zrównoważona. Warszawa: Wydawnictwo Naukowe PWN, 21-43.

Dziedzic, E. (1998). Obszar recepcji turystycznej jako przedmiot zarządzania strategicznego. Monografie i Opracowania Szkoły Głównej Handlowej, 442.

Eccles, G. (1995). Marketing, sustainable development and international tourism. International Journal of Contemporary Hospitality Management, 7(7), 20-26.

Flejterski, S., Klóska, R., Majchrzak, M. (2005). Tendencje rozwoju sektora usług. W: S. Flejterski, A. Panasiuk, J. Perenc, G. Rosa (red.). Współczesna ekonomika usług. Warszawa: Wydawnictwo Naukowe PWN, 36-40.

Hudson, S. (1996). The 'greening' of ski resorts: a necessity for sustainable tourism, or a marketing opportunity for skiing communities? Journal of Vacation Marketing, 2(2), 176-185.

Hudson, S., Miller, G.A. (2005). The responsible marketing of tourism: the case of Canadian Mountain Holidays. Tourism Management, 26(2), 133-142.

Hunter, C. (1997). Sustainable tourism as an adaptive paradigm. Annals of Tourism Research, 24(4), 850-867.

Jedlińska, M. (2007). Zachowanie klienta na rynku usług turystycznych. W: A. Panasiuk (red.). Marketing usług turystycznych. Warszawa: Wydawnictwo Naukowe PWN, 45-61.

Jędrzejczyk, I. (1995). Ekologiczne uwarunkowania i funkcje turystyki. Katowice: Wydawnictwo Śląsk.

Kiełczewski, D. (2012). Różnorodność stylów życia jako czynnik rozwoju zrównoważonego. Ekonomia i Środowisko, 3(43), 73-84.

Kłos, A. (2013). Proekologiczne rozwiązania w obiektach hotelarskich. Zeszyty Naukowe. Turystyka i Rekreacja, 1(11), 147-162.

Kramer, J. (2011). Konsumpcja - ewolucja ról i znaczeń. Konsumpcja i Rozwój, 1, 5-15.

Kruczek, Z., Sacha, S. (1995). Geografia atrakcji turystycznych Polski. Kraków: Oficyna Wydawnicza Ostoja. 
Kurek, W. (1999). Rozwój turystyki i jej wpływ na środowisko przyrodnicze Alp. Turyzm, 9(1), 161-172.

Kurek, W. (2004). Turystyka na obszarach górskich Europy. Kraków: Wydawnictwo Uniwersytetu Jagiellońskiego.

Kurleto, M. (2013). Współczesne oddziaływanie polityki państwowej na rozwój przedsiębiorstw związanych z turystyką. Zarządzanie i Finanse, 1(11), 411-427.

Meyer, B. (2010). Nowe trendy w kształtowaniu produktów turystycznych. Acta Scientiarum Polonarum, Oeconomia, 9(4), 313-322.

Niezgoda, A. (2006). Obszar recepcji turystycznej w warunkach rozwoju zrównoważonego. Prace habilitacyjne, 24.

Niezgoda, A. (2010). Ekologiczne uwarunkowania zachowań nabywczych w turystyce. Zeszyty Naukowe Uniwersytetu Szczecińskiego. Ekonomiczne problemy usług, 52, 643-652.

Niezgoda, A. (2011). The role of Environmental Knowledge, Attitudes and Initiatives in the Development of Tourism Product. Turism, 21(1-2), 33-39.

Panasiuk, A. (2007). Koncepcja marketingowa w turystyce. W: A. Panasiuk (red.). Marketing usług turystycznych. Warszawa: Wydawnictwo Naukowe PWN, 62-73.

Pawlicz, A., Sidorkiewicz, M. (2013). Ekologia jako podstawa innowacyjnego produktu hotelarskiego. W: P. Dominik (red.). Innowacyjne rozwiq̨zania we współczesnym hotelarstwie. Warszawa: Almamer Szkoła Wyższa. Wydział Turystyki i Rekreacji, 195-207.

Rosa, G. (2005). Przyczyny wzrostu znaczenia sektora usług. W: S. Flejterski, A. Panasiuk, J. Perenc, G. Rosa (red.). Współczesna ekonomika usług. Warszawa: Wydawnictwo Naukowe PWN, 59-63.

Smerecnik, K.R., Andersen, P.A. (2011). The diffusion of environmental sustainability innovations in North American hotels and ski resorts. Journal of Sustainable Tourism, 19(2), 171-196.

Sumień, T. (1998). Idea zrównoważonego rozwoju w nowym systemie standardów urbanistycznych. Człowiek i Środowisko, 22, 7-24.

Sztumski, W. (2006). Idea zrównoważonego rozwoju a możliwości jej urzeczywistnienia. Problemy Ekorozwoju, 1(2), 73-76.

Todd, S.E., Williams, P.W. (1996). From white to green: A proposed environmental management system framework for ski areas. Journal of Sustainable Tourism, 4(3), 147-173.

Tourism Concern (2012) (2016, 19 grudnia). Water Equity in Tourism - A Human Right, A Global Responsibility. Pozyskano z http://www.tourismconcern.org.uk/

Turystyka i środowisko (1994). Tourin. Dodatek do Rynku Turystycznego, 9.

UNWTO (2013). UNWTO World Tourism Barometer, 11.

UNWTO (2015). UNWTO World Tourism Barometer, 13.

Ustawa z dnia 27 kwietnia 2001 r. Prawo ochrony środowiska (Dz.U. z 2001 r. nr 62, poz. 627).

Vera Rebollo, J.F., Ivars Baidal, J.A. (2003). Measuring sustainability in a mass tourist destination: Pressures and Policy responses in Torrevieja, Spain. Journal of Sustainable Tourism, 11(2-3), 181-203.

Wasilik, K. (2014). Trendy w zachowaniach współczesnych konsumentów - konsumpcjonizm a konsumpcja zrównoważona. Konsumpcja i Rozwój, 1(6), 66-74.

Witek, J. (2011). Zachowania konsumentów - wyzwaniem rynku. W: J. Perenc, G. Rosa (red.). Zachowania nabywców. Szczecin: Wydawnictwo Naukowe Uniwersytetu Szczecińskiego, 9-23.

Włodarczyk-Śpiewak, K. (2011). Konsumpcja jako przedmiot badań ekonomicznych. Ruch Prawniczy, Ekonomiczny i Socjologiczny, 3, 63-80.

Zalejski, J., Faszczewska, K. (2012). Zachowania polskich konsumentów wobec produktów ekologicznych. Ekonomia i Zarządzanie, 3, 92-104.

Zaręba, D. (2010). Ekoturystyka. Wyzwania i nadzieje. Warszawa: Wydawnictwo Naukowe PWN.

Zdon-Korzeniowska, M., Rachwał, T. (2011). Turystyka w warunkach światowego kryzysu gospodarczego. Prace Komisji Geografii Przemysłu Polskiego Towarzystwa Geograficznego, 18, 116-128. 
Żabińska, T. (2000). Marketing a rozwój turystyki zrównoważonej. W: S. Bosiacki (red.). Gospodarka turystyczna u progu XXI wieku. Poznań: Wydawnictwo Akademii Wychowania Fizycznego w Poznaniu.

Żemła, M. (2010a). Wartość dla klienta w procesie kształtowania konkurencyjności obszaru recepcji turystycznej. Katowice: Wydawnictwo Górnośląskiej Wyższej Szkoły Handlowej w Katowicach.

Żemła, M. (2010b). Zrównoważony rozwój turystyki - problemy i dylematy. Zeszyty Naukowe Górnośląskiej Wyższej Szkoły Handlowej w Katowicach, 40, 11-30.

Żemła, M. (2013). Turystyka zrównoważona. W: D. Chudy-Hyski, M. Żemła (red.). Turystyka bardziej przyjazna. Wybrane zagadnienia minimalizacji negatywnego wpływu turystyki na środowisko przyrodnicze. Katowice: Wydawnictwo Górnośląskiej Wyższej Szkoły Handlowej w Katowicach, 49-62.

Marek Hendel, magister, doktorant kierunku ekonomia na Wydziale Ekonomii, Zarządzania i Turystyki Uniwersytetu Ekonomicznego we Wrocławiu. Pracownik dydaktyczny Górnośląskiej Wyższej Szkoły Handlowej w Katowicach. Zainteresowania badawcze związane są ze zrównoważonym rozwojem turystyki, zachowaniami konsumentów na rynku turystycznym oraz rolą samorządu terytorialnego w rozwoju turystyki.

Marek Hendel, M.Sc., Ph.D. student in the field of Economics at the Wroclaw University of Economics, Faculty of Economics, Management and Tourism in Jelenia Gora. He is a member of the teaching staff in Katowice School of Economics. His research interests are related to sustainable tourism development, consumers behavior on the tourist market and the role of local government in tourism development.

\section{Adres/address:}

Uniwersytet Ekonomiczny we Wrocławiu Wydział Ekonomii, Zarządzania i Turystyki w Jeleniej Górze ul. Nowowiejska 3, 58-500 Jelenia Góra, Polska e-mail: hendel.marek@gmail.com

Michał Żemła, dr hab., prof. Uniwersytetu Pedagogicznego w Krakowie, w Instytucie Geografii, Zakładzie Turystyki i Badań Regionalnych. Ukończył studia magisterskie na Wydziale Organizacji i Zarządzania Politechniki Śląskiej w Gliwicach, otrzymał doktorat na Akademii Ekonomicznej w Katowicach, a habilitację na Uniwersytecie Ekonomicznym we Wrocławiu. Jego zainteresowania badawcze są związane z marketingiem obszarów turystycznych ze specjalnym uwzględnieniem obszarów górskich. Jest autorem lub współautorem trzech książek i prawie 100 artykułów naukowych.

Michał Żemła, Ph.D., associate professor, Pedagogical University of Cracow, Institute of Geography, Department of Tourism and Regional Studies. He graduated at the Faculty of Organization and Management of the Silesian University of Technology in Gliwice, he obtained his Ph.D. at the Economic University in Katowice and habilitation at the Economic University in Wroclaw. For many years he has been working in Katowice School of Economics. His research interests are connected with tourism destinations marketing, with special regards put to mountain areas. He is an author or co-author of 3 books and almost 100 scientific papers.

\section{Adres/address:}

Uniwersytet Pedagogiczny w Krakowie Wydział Geograficzno-Biologiczny, Instytut Geografii ul. Podchorążych 2, 30-084 Kraków, Polska e-mail: michal.zemla@up.krakow.pl 